\title{
Behavior of Pulsed Electric Fields Injured Escherichia coli 0157:H7 Cells in Apple Juice Amended with Pyruvate and Catalase
}

\section{Dike Ukuku ${ }^{1 *}$, Hyung-Gyun Yuk ${ }^{2}$ and HOWARD ZHANG ${ }^{3}$}

${ }^{1}$ Food Safety Intervention Technologies Research Unit, Eastern Regional Research Center, Agricultural Research Service, U.S. Department of Agriculture, 600 East Mermaid Lane, Wyndmoor, Pennsylvania 19038, USA

${ }^{2}$ Food Science and Technology Programme, Department of Chemistry, National University of Singapore, Science Drive 4, Singapore 117543, Republic of Singapore ${ }^{3}$ Western Regional Research Center, Agricultural Research Service, U.S. Department of Agriculture, 800 Buchanan Street, Albany, California 94710 , USA

\section{Abstract}

Pulse Electric Field (PEF) treatment has been used to inactivate bacteria in liquid foods. However, information on the behavior of PEF injured Escherichia coli bacteria in media during storage at 5 and $23^{\circ} \mathrm{C}$ are limited. In this study, we investigated the fate of $E$. coli $\mathrm{O} 157: \mathrm{H} 7$ cells at $6.8 \mathrm{log} \mathrm{CFU} / \mathrm{ml}$ in apple juice treated with PEF at $7.2 \mathrm{kV} / \mathrm{cm}$ and 32.2 $\mathrm{kV} / \mathrm{cm}, 18.4 \mathrm{~A}$ with pulse width of $2.6 \mu \mathrm{s}$ at $25,35,45$ and $55^{\circ} \mathrm{C}$, at a flow rate of $120 \mathrm{ml} / \mathrm{min}$. The juices collected were amended with pyruvate and catalase ( 0 to $0.1 \%)$ and then stored at 5 and $23^{\circ} \mathrm{C}$ for $24 \mathrm{~h}$. Periodically $(0,3,6$, and $24 \mathrm{~h})$, $0.1 \mathrm{ml}$ of the treated sample was plated on Sorbitol MacConkey Agar (SMAC) and Tryptic Soy Agar (TSA) amended with catalase and pyruvate to determine percent injury, viability loss and behavior of injured cells. PEF voltage at $32.2 \mathrm{kV} / \mathrm{cm}$ and treatments at 35,45 and $55^{\circ} \mathrm{C}$ led to significant decline in the surviving cell populations than treatment at $7.2 \mathrm{kV} /$ $\mathrm{cm}$. The injured populations in control media were higher than media amended with pyruvate and catalase suggesting possible recovery of PEF injured E. coli cells.

Keywords: PEF; Injury; Inactivation; E. coli; Apple juice; Catalase and pyruvate

\section{Introduction}

Food manufacturers and distributors are responding to consumers' demand for food products that receive no heat or minimal heat treatment, safe, fresh and convenient (Ukuku and Geveky, 2010). In some cases foods may be improperly processed and/or contaminated with spoilage bacteria or human bacterial pathogens during processing, storage or distribution (Alex et al., 2001; Cody et al., 1999). Thermal processing used by the juice industry to inactivate food borne pathogens impairs the characteristic flavor of juices (Linton et al., 1999; Mazzotta, 2001). Therefore there is a need for alternative processing treatments that can achieve a $5 \mathrm{log}$ reduction of these pathogens (Sizer and Balasubramaniam, 1999; Mazzotta, 2001) without causing adverse effect on the flavor of the juice.

There are several reports on non-thermal pasteurization process using pulse electric fields (PEF) to inactivate bacteria in liquid foods (Hulsheger, et al., 1983; Jeyamkondan, et al., 1999; Zhao et al., 2008; Dutreux et al., 2000). In these studies, a set of PEF operating parameters that achieved $99.999 \%(5 \mathrm{logs})$ reduction of $E$. coli in apple cider was determined, and the kinetics of bacterial inactivation established (Min et al., 2003). However, the current knowledge of PEF processes and its mechanisms for inactivation of bacterial pathogen is limited. It was hypothesized that PEF inactivation is caused by rupture of bacteria membrane structure through application of high voltage electric fields to the bacteria (Zimmerman et al., 1976; Zimmerman, 1986). Most aerobic and facultative bacteria that utilize oxygen produce hydrogen peroxide $\left(\mathrm{H}_{2} \mathrm{O}_{2}\right)$, which is toxic to their own enzyme systems. Therefore, this class of bacteria produces catalase in small amount during logarithmic growth (Martin et al., 1976) to counteract the toxic effect of $\mathrm{H}_{2} \mathrm{O}_{2}$. The catalase produced by bacteria is attached to the intracellular membrane (Kovacs et al., 1966; Lin, 1963) and if the membrane structure is ruptured as proposed, then the catalase attached at this site becomes dysfunctional. In this study, we hypothesized that the addition of membrane associated pyruvate and catalase to PEF injured E. coli cells in apple juice will aid cellular repair of PEF injured E. coli populations. The results obtained in this study will provide more information leading to the understanding of the mechanism of PEF inactivation of bacteria.

\section{Materials and Method}

\section{Test strains and preparation of inocula}

Apple juice -related E. coli 0157:H7 outbreaks (SEA13B88) and (Oklahoma) from the U.S. Department of Agriculture, Agricultural Research Service, Eastern Regional Research Center culture collection was used in this study. Cell culture was maintained on tryptic soy agar (TSA) at $4^{\circ} \mathrm{C}$. Prior to use the cells were inoculated by loop in tryptic soy broth (TSB: Remel, Inc., Lenexa, KS) and then incubated at $37^{\circ} \mathrm{C}$ for $16-18 \mathrm{~h}$ with shaking. A $0.1 \mathrm{ml}$ cell aliquot was transferred to $100 \mathrm{ml}$ of TSB and incubated at $37^{\circ} \mathrm{C}$ for $24 \mathrm{~h}$. The overnight cell suspensions were centrifuged at $3,000 \mathrm{~g}$ for $10 \mathrm{~min}$ at $5^{\circ} \mathrm{C}$. The cell pellets were washed with equal volume $(100 \mathrm{ml})$ of sterile phosphatebuffered saline (PBS, pH 7.2) solution. Finally, individual washed cells were combined and resuspended in $100 \mathrm{ml} \mathrm{PBS}$ at $10^{9} \mathrm{CFU} / \mathrm{ml}$ and used as the inoculum.

*Corresponding author: Dike Ukuku, Food Safety Intervention Technologies Research Unit, Eastern Regional Research Center, Agricultural Research Service, U.S. Department of Agriculture, 600 East Mermaid Lane, Wyndmoor, Pennsylvania 19038, USA, Tel: +1-215-233-6427; Fax: +1-215-233-6406; E-mail: dike.ukuku@ ars.usda.gov

Received September 02, 2010; Accepted September 22, 2010; Published September 22, 2010

Citation: Ukuku D, Yuk HG, Zhang H (2010) Behavior of Pulsed Electric Fields Injured Escherichia coli O157:H7 Cells in Apple Juice Amended with Pyruvate and Catalase. J Microbial Biochem Technol 2: 134-138. doi:10.4172/19485948.1000038

Copyright: ( 2010 Ukuku D, et al. This is an open-access article distributed under the terms of the Creative Commons Attribution License, which permits unrestricted use, distribution, and reproduction in any medium, provided the original author and source are credited. 


\section{Sample preparation}

Apple juice concentrate $(1.30 \mathrm{~L})$ purchased from a local store was mixed with deionize sterile water $(8.30 \mathrm{~L})$ at room temperature $\left(\sim 23^{\circ} \mathrm{C}\right)$. E. coli prepared as above was added to the apple juice at approximately $10^{7} \mathrm{CFU} / \mathrm{ml}$, mixed and a serial dilution was prepared. A $0.1 \mathrm{ml}$ of the diluted samples was plated in duplicate on TSA and SMAC with incubation at $36^{\circ} \mathrm{C}$ for $24 \mathrm{~h}$ to determine the initial number of colony forming unit (CFU) in the apple juice before PEF treatment. Similarly, the apple juice without the inoculated populations of $E$. coli bacteria was plated on TSA and SMAC with incubation at $36^{\circ} \mathrm{C}$ for 24 h to determine if $E$. coli is present on the sample.

\section{Pulsed electric fields treatment and processing variables}

Inoculated apple juice was allowed to stand at room temperature for up to $2 \mathrm{~h}$ before being pumped through the pulsed electric field (PEF) chamber (0.29 electrode-gap distance, with a treatment volume of $0.012 \mathrm{~cm}^{3}$ ) at a rate of $120 \mathrm{ml} / \mathrm{min}$. A peak voltage of $7.4 \mathrm{kV} / \mathrm{cm}$, peak current of 18.4 ampere and a pulse width of $2.6 \mu \mathrm{s}$ at $55^{\circ} \mathrm{C}$ were applied. In another study, we increased the peak voltage to $32.2 \mathrm{kV} /$ $\mathrm{cm}$, while the treatment parameters listed above were maintained as is. The maximum treatment temperature was kept below $57^{\circ} \mathrm{C}$, using a cooling coil, which was connected between each pair of chambers and submerged in an iced water bath. Thermocouples were attached to the stainless-steel coils, $2.5 \mathrm{~cm}$ away from the PEF zones along the flow direction. The temperatures of the inlet and outlet of each pair of chambers were recorded every $0.1 \mathrm{~s}$. The characteristics of the electric pulses delivered such as shape, polarity, width, difference of potential as well as the electric current generated across the electrodes and the pulse frequency were monitored using a digital oscilloscope (model THS720, Tektronix Inc., Beaverton, OR, USA). The water bath temperature was adjusted to give similar outlet temperatures as stated above. Samples $(\sim 20 \mathrm{ml})$ at each outlet temperatures were individually collected and analyzed for bacterial cell survivors, injured cells and viability loss as stated below.

\section{Preparation of pyruvate and catalase}

Pyruvate and catalase (Sigma-Aldrich, St. Louis MO, USA) were individually dissolved in $\mathrm{ddH}_{2} \mathrm{O}$, filter sterilized using $0.45 \mu 150 \mathrm{ml}$ analytical filter unit (Nalgnene, Rochester, NY) and added to the PEF treated apple juice containing injured E. coli cells at a final concentration of $0,0.01,0.05$ and $0.1 \%$ each. Also, tryptic soy agar (TSA) and Sorbitol MacConkey Agar (SMAC) plates were amended with pyruvate and catalase at a final concentration of $0,0.01,0.05$ and $0.1 \%$ each.

\section{Microbial injury and viability loss}

To determine the initial number of surviving $E$. coli population including injured cells after PEF treatment of apple juice, an aliquot $(0.1 \mathrm{ml})$ of the apple juice described above was plated on TSA, TSA $+0.1 \%$ Catalase (TSA-cat), TSA $+0.1 \%$ Pyruvate (TSA-pyr), Sorbitol MacConkey Agar (SMAC) and SMAC+ 0.1\% Pyruvate (SMAC-pyr) and $\mathrm{SMAC}+0.1 \%$ Catalase plates. All plated samples were incubated at $36^{\circ} \mathrm{C}$ for $48 \mathrm{~h}$ to determine the colony forming unit (CFU/ml). The difference in populations of $E$. coli enumerated on selective versus non-selective media was considered as injured cells, and the percent injury was calculated using this formula:

[1- (colonies on selective agar/counts on nonselective) $] \times 100$

The number $\mathrm{CFU} / \mathrm{ml}$ on selective agar media was used to calculate the viability loss which is defined as the differences in $\log C F U / m l$ of bacteria between control and PEF-treated samples (Linton et al., 1999).

\section{PEF injured E. Coli bacteria during storage}

The population of untreated $E$. coli cells and those surviving the PEF treatments of apple juice amended with or without $0,0.01,0.05$ and $0.1 \%$ catalase and pyruvate were investigated during storage at 5 and $23^{\circ} \mathrm{C}$. Periodically $(0,3,6$, and $24 \mathrm{~h})$, an aliquot $(0.1 \mathrm{ml})$ of each sample was plated on TSA, TSA+0.1\% catalase (TSA-cat), TSA $+0.1 \%$ pyruvate (TSA-pyr), Sorbitol MacConkey Agar (SMAC) and SMAC $+0.1 \%$ pyruvate (SMAC-pyr) and SMAC $+0.1 \%$ catalase plates to determine the number of colony forming unit (CFU/ml). Untreated PEF inoculated apple juice was used as controls for each experiment.

\section{Data analysis}

All experiments were performed in triplicate with duplicate samples being analyzed at each sampling time. Data were subjected to analysis of variance (ANOVA) using the Statistical Analysis System Program (SAS Institute, Cary, NC, USA). Significant differences $(p<0.05)$ between mean values of number of cells in media amended with or without catalase and pyruvate were determined by the Bonferroni least significant difference (LSD) method (Miller, 1981).

\section{Results and Discusion}

\section{Untreated $E$. coli cells}

There was no E. coli population determined in freshly prepared apple juice before the inoculation and PEF treatments. The populations of $E$. coli cells inoculated in apple juice before PEF treatment averaged 6.8 and $6.5 \operatorname{logs}$ on TSA and SMAC, respectively. After PEF treatment at $7.2 \mathrm{kV} / \mathrm{cm}$, the populations of $E$. coli cells in apple juice were reduced by $1.2 \log \mathrm{CFU} / \mathrm{ml}$ and the surviving populations in apple juice amended with $0,0.1,0.05$ and $0.1 \%$ pyruvate or catalase increased slightly during storage at $23^{\circ} \mathrm{C}$ for $24 \mathrm{~h}$ (Figure 1 ). The populations of surviving $E$. coli cells in apple juice amended with catalase were slightly higher than in juices amended with pyruvate but again these numbers were not significantly $(p<0.05)$ different. Populations in juices amended with $0.1 \%$ catalase or pyruvate were slightly higher than the rest of the concentration therefore a concentration of $0.1 \%$ for catalase and pyruvate was used for the rest of the study. The results of this study indicate that a trace amount of catalase in apple juice enhanced the recovery and survival of PEF injured $E$. coli cells during storage at $23^{\circ} \mathrm{C}$ for $24 \mathrm{~h}$.

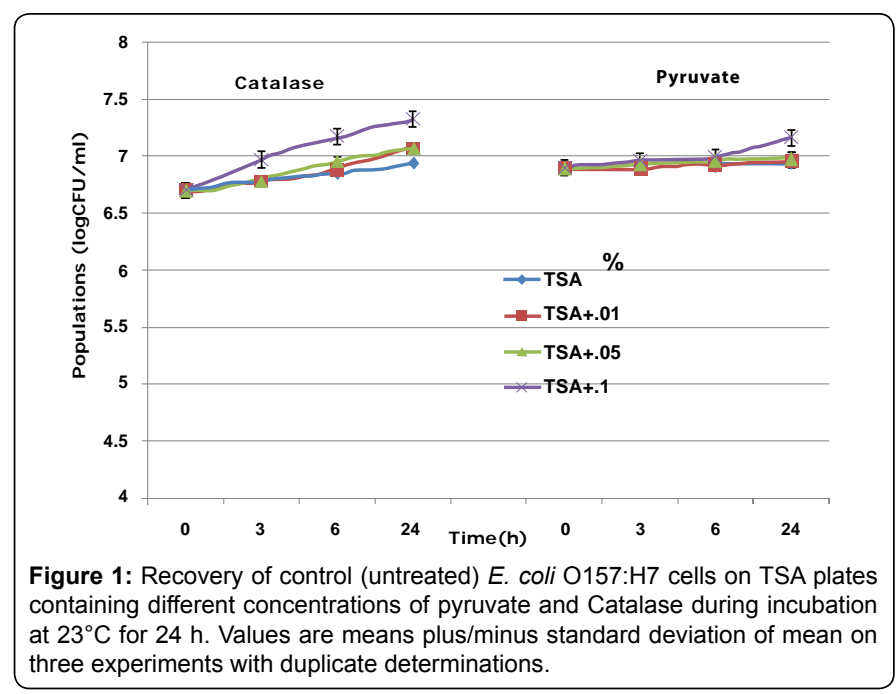



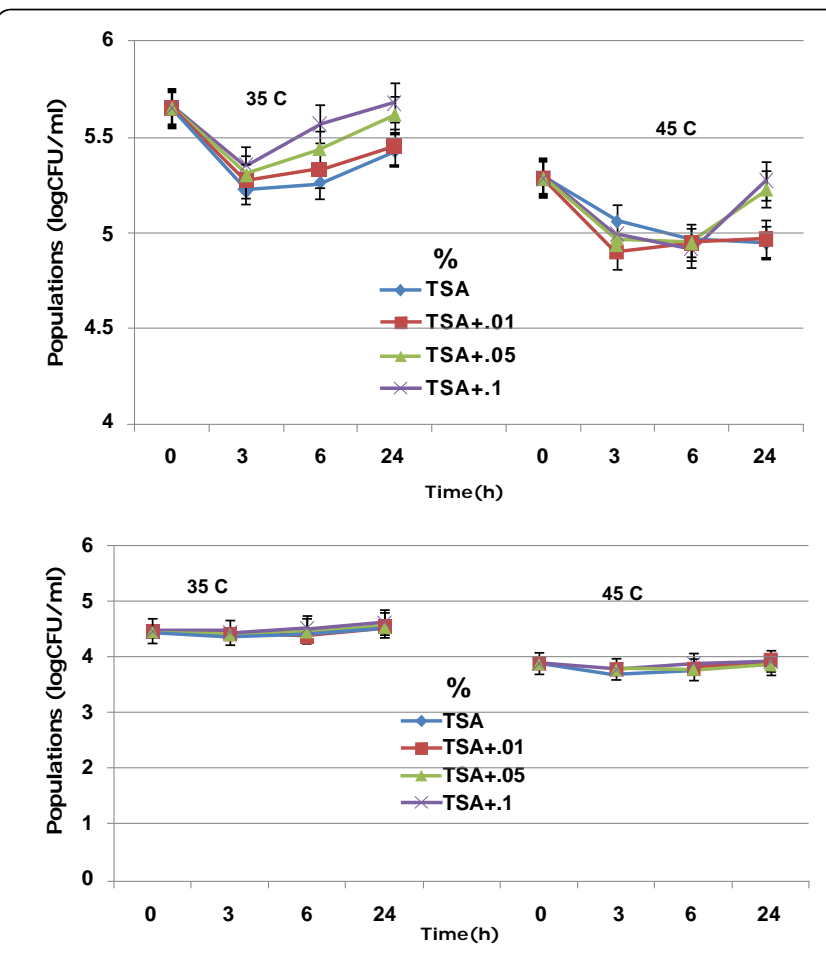

Figure 2: Recovery of PEF treated E. coli O157:H7 cells on TSA plates containing different concentrations of pyruvate (2B) and Catalase (2A) during incubation at $23^{\circ} \mathrm{C}$ for $24 \mathrm{~h}$. Values are means plus/minus standard deviation of mean on three experiments with duplicate determinations.

\section{Behavior of PEF injured $E$. coli cells in media amended with} pyruvate or catalase

The effect of $7.2 \mathrm{kV} / \mathrm{cm}$ PEF treatment at $35^{\circ} \mathrm{C}$ and $45^{\circ} \mathrm{C}$ on the population of E. coli cells in apple juice is shown in (Figure 2A). The populations of the surviving $E$. coli cells averaged $5.7 \mathrm{log}$ and 5.3 $\log \mathrm{CFU} / \mathrm{ml}$, respectively. The E. coli populations decreased during storage at $23^{\circ} \mathrm{C}$ for $3 \mathrm{~h}$ in all apple juice amended with catalase including the control. At $6 \mathrm{~h}$ of storage, $E$. coli cells begin to revive and by $24 \mathrm{~h}$ the populations were approximately close to the initial numbers started with. The initial populations of surviving $E$. coli cells in apple juice treated at $45^{\circ} \mathrm{C}$ averaged $5.4 \log \mathrm{CFU} / \mathrm{ml}$. Again, all populations declined to $<5.0 \mathrm{log} \mathrm{CFU} / \mathrm{ml}$ at $3 \mathrm{~h}$ during storage and the numbers remained the same up to $24 \mathrm{~h}$ with the exception of juices amended with 0.05 and $0.1 \%$ catalase. In apple juice similarly treated and amended with pyruvate, the $E$. coli cell populations did not decline but remained relatively the same up to $24 \mathrm{~h}$ of storage at $23^{\circ} \mathrm{C}$ (Figure 2B).

The results of PEF treatment at $32.2 \mathrm{kV} / \mathrm{cm}$ and treatment temperatures at 35,45 and $55^{\circ} \mathrm{C}$ on the surviving $E$. coli cell populations determined on TSA and SMAC plates is shown (Table 1). The surviving treated $\mathrm{PEF}$ treatment at $35^{\circ} \mathrm{C}$ reduced the surviving E. coli populations in apple juice to an average of $4.95 \mathrm{log}$ and $4.96 \log \mathrm{CFU} / \mathrm{ml} \mathrm{s}$ on TSA and TSA-pyr, respectively. However, the populations on SMAC and SMAC-pyr plates were 4.85 and $4.92 \log$ $\mathrm{CFU} / \mathrm{ml}$, respectively. PEF treatment at higher temperatures (45 and $55^{\circ} \mathrm{C}$ ) resulted to a significant reduction of the surviving populations. The E. coli populations determined on TSA plates after PEF treatment at 45 and $55^{\circ} \mathrm{C}$ averaged 3.89 and $3.90 \log \mathrm{CFU} / \mathrm{ml}$ and 2.69 and 2.42 $\log \mathrm{CFU} / \mathrm{ml}$ on SMAC plates, respectively. Recovery of PEF injured E. coli cells on TSA- pyr averaged 3.93 and $3.95 \mathrm{log} \mathrm{CFU} / \mathrm{ml}$ at 45

\begin{tabular}{|l|l|l|l|l|}
\hline & $\begin{array}{l}\text { TSA }+ \\
\text { Pyruvate }\end{array}$ & TSA & $\begin{array}{l}\text { SMAC + } \\
\text { Pyruvate }\end{array}$ & SMAC \\
\hline IC & $6.75 \pm 0.15^{\mathrm{A}}$ & $6.76 \pm 0.15^{\mathrm{A}}$ & $6.85 \pm 0.14^{\mathrm{A}}$ & $6.69 \pm 0.16^{\mathrm{A}}$ \\
\hline $\mathrm{T} 1\left(35^{\circ} \mathrm{C}\right)$ & $4.96 \pm 0.12^{\mathrm{BA}}$ & $4.95 \pm 0.14^{\mathrm{BA}}$ & $4.72 \pm 0.14^{\mathrm{BC}}$ & $4.85 \pm 0.13^{\mathrm{BB}}$ \\
\hline $\mathrm{T} 2\left(45^{\circ} \mathrm{C}\right)$ & $3.93 \pm 0.14^{\mathrm{CA}}$ & $3.89 \pm 0.12^{\mathrm{CA}}$ & $2.87 \pm 0.12^{\mathrm{CB}}$ & $2.69 \pm 0.12^{\mathrm{CC}}$ \\
$\mathrm{T}^{\circ}\left(55^{\circ} \mathrm{C}\right)$ & $3.95 \pm 0.12^{\mathrm{CA}}$ & $3.90 \pm 0.10^{\mathrm{CA}}$ & $2.82 \pm 0.10^{\mathrm{CA}}$ & $2.42 \pm 0.12^{\mathrm{CB}}$ \\
\hline
\end{tabular}

TSA $=$ tryptic soy agar plates

TSA + Pyruvate $=$ TSA plus Pyruvate $(0.1 \%)$

SMAC $=$ Sorbitol McConkey agar plates

SMAC + Pyruvate $=$ Sorbitol McConkey agar plates plus Pyruvate $(0.1 \%)$

Values are means \pm SD of three experiments with duplicate determinations per experiment.

Means in each row and column not followed by the same letter are significantly $(p<0.05)$ different

Table 1: Effect of PEF treatment temperature on populations of Escherichia coli in different media plates containing $0.1 \%$ pyruvate.

\begin{tabular}{|l|l|l|l|l|}
\hline & $\begin{array}{l}\text { TSA }+ \\
\text { Catalase }\end{array}$ & TSA & $\begin{array}{l}\text { SMAC + } \\
\text { Catalase }\end{array}$ & SMAC \\
\hline IC & $6.76 \pm 0.15^{\text {AA }}$ & $6.78 \pm 0.15^{\mathrm{AA}}$ & $6.82 \pm 0.14^{\mathrm{AA}}$ & $6.66 \pm 0.15^{\mathrm{AA}}$ \\
\hline $\mathrm{T} 1\left(35^{\circ} \mathrm{C}\right)$ & $5.16 \pm 0.12^{\mathrm{BA}}$ & $5.14 \pm 0.12^{\mathrm{BA}}$ & $5.01 \pm 0.13^{\mathrm{BA}}$ & $5.08 \pm 0.12^{\mathrm{BA}}$ \\
\hline $\mathrm{T} 2\left(45^{\circ} \mathrm{C}\right)$ & $3.86 \pm 0.10^{\mathrm{CA}}$ & $3.54 \pm 0.10^{\mathrm{CA}}$ & $2.59 \pm 0.10^{\mathrm{CB}}$ & $2.48 \pm 0.12^{\mathrm{CB}}$ \\
$\mathrm{T}^{\circ}\left(55^{\circ} \mathrm{C}\right)$ & $3.65 \pm 0.12^{\mathrm{CA}}$ & $3.32 \pm 0.12^{\mathrm{CA}}$ & $2.54 \pm 0.10^{\mathrm{CB}}$ & $2.36 \pm 0.10^{\mathrm{CB}}$ \\
\hline
\end{tabular}

TSA $=$ tryptic soy agar plates

TSA + Catalase $=$ TSA plus Catalase $(0.1 \%)$

SMAC $=$ Sorbitol McConkey agar plates

SMAC + Catalase $=$ Sorbitol McConkey agar plates plus Catalase $(0.1 \%)$

Values are means \pm SD of three experiments with duplicate determinations per experiment.

Means in each row and column not followed by the same letter are significantly $(p<0.05)$ different

Table 2: Effect of PEF treatment temperature on populations of Escherichia coli in different media plates containing $0.1 \%$ Catalase.

and $55^{\circ} \mathrm{C}$, respectively. Populations determined on SMAC- pyr plates were slightly lower and averaged 2.87 and $2.82 \log \mathrm{CFU} / \mathrm{ml}$ at 45 and $55^{\circ} \mathrm{C}$, respectively. E. coli cell populations recovered on TSA and SMAC amended with or without catalase showed similar trend observed on plates amended with pyruvate (Table 2). The addition of $0.1 \%$ pyruvate (Table 1 ) or catalase (Table 2) to the agar plates slightly enhanced the recovery of $E$. coli cell populations, however, the number of cells determined on TSA and SMAC plates containing pyruvate and catalase were not significantly $(p<0.05)$ different. The surviving population of $E$. coli cells determined immediately after PEF treatments of apple juice decreased as treatment temperature decreased from $55^{\circ} \mathrm{C}$ to $35^{\circ} \mathrm{C}$., respectively.

Approximately 20, 93 and $97 \%$ of the surviving E. coli populations determined in apple juice immediately after PEF treatment at 35, 45 and $55^{\circ} \mathrm{C}$ were injured (Figure 3). In this study, both catalase and pyruvate and storage at $23^{\circ} \mathrm{C}$ for $24 \mathrm{~h}$ appeared to help recovery of PEF injured $E$. coli cells (Figure 3). Storage of PEF treated $E$. coli cells in apple juice amended with $0.1 \%$ catalase and pyruvate at $5^{\circ} \mathrm{C}$ for 24 $\mathrm{h}$ led to further decline of injured cells irrespective of the presence or absence of catalase or pyruvate (Figure 4). However, the decline of injured $E$. coli cells in apple juice amended with catalase and pyruvate was slower than the populations in the control. Addition of $0.1 \%$ pyruvate to the PEF treated apple juice decreased the populations of injured $E$. coli cells from 20 to $2.3 \%, 94$ to $9.6 \%$ and 97 to $12.2 \%$ in juices treated at 35,45 and $55^{\circ} \mathrm{C}$, respectively. Again, catalase appeared to be more effective in repair and recovery of PEF injured $E$. coli cells than the pyruvate. For example, the injured $E$. coli populations recovered and the percent injured cells determined averaged $4.7,4.7$ and $7.1 \%$ in 35,45 and $55^{\circ} \mathrm{C}$, respectively in PEF treated apple juices. Though this effect appeared to be minimal in 


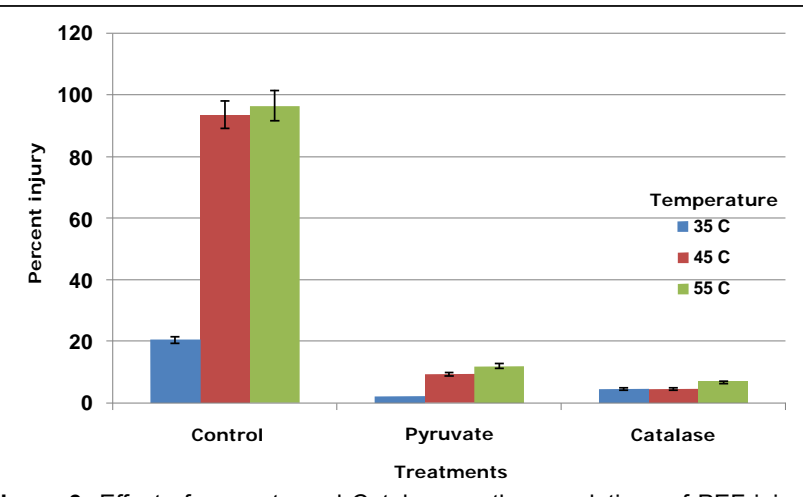

Figure 3: Effect of pyruvate and Catalase on the populations of PEF injured E. coli $\mathrm{O} 157: \mathrm{H} 7$ cells treated at different temperatures Values are means plus/ minus standard deviation of mean on three experiments with duplicate determinations.

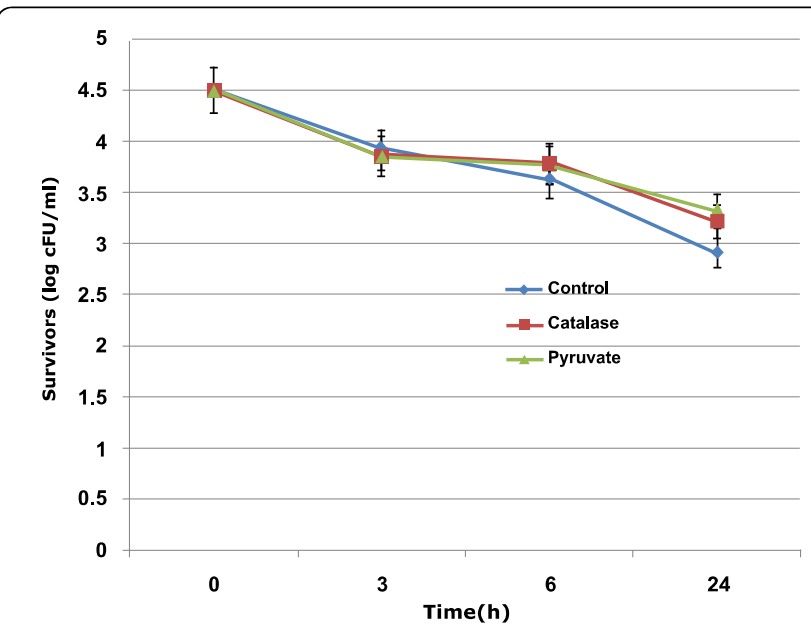

Figure 4: Effect of refrigeration $\left(5^{\circ} \mathrm{C}\right)$ storage for $24 \mathrm{~h}$ on $\mathrm{PEF}$ injured $\mathrm{E}$. coli O157: $\mathrm{H} 7$ cells in apple juice amended with $0.1 \%$ pyruvate and Catalase Values are means plus/minus standard deviation of mean on three experiments with duplicate determinations.

plate count data, the results of this study is in agreement with the Mackey and Seymour (1987) study that reported a protective effect of catalase and peroxidase in heat injured $E$. coli cells.

It has been reported that PEF inactivation is caused by rupture of bacteria membrane structure through application of high voltage electric fields to the bacteria (Zimmerman et al., 1976; Zimmerman, 1986). This effect may have caused the bacteria membrane bound catalase, to be disrupted and non functional. It has been reported that accumulation of $\mathrm{H}_{2} \mathrm{O}_{2}$ is a universal phenomenon associated with cellular injury following sublethal stress (Martin et al., 1976) and this contributes to the cell death. As a result of the PEF treatment, it is possible that the dysfunctional membrane catalase and or pyruvate was not able to clear/destroy the accumulated $\mathrm{H}_{2} \mathrm{O}_{2}$. Therefore, the injured $E$. coli cells were not able to convert cellular substrates needed for cell metabolism which ultimately led to the death of PEF injured E. coli cells. The slight recovery of injured $E$. coli cells observed in apple juice was a result of the catalase or the pyruvate added to the PEF treated apple juice. Other researchers have proposed a mode of action of sodium pyruvate to be through the degradation of the metabolic by-product hydrogen peroxide $\left(\mathrm{H}_{2} \mathrm{O}_{2}\right)$, rather than through supplementation of a required nutrient (BairedParker and Davenport, 1965). This is the first study to look into the behavior of PEF injured $E$. coli cells in the presence of catalase or pyruvate towards understanding the mechanism of inactivation of bacteria by PEF. Further study in this area is needed to clearly understand and elucidate the mechanism of PEF inactivation of bacteria in liquid foods. In conclusion, the results of the present study suggest that catalase and pyruvate did provide minimal aid to cellular repair of injured PEF treated $E$. coli cells in apple juice stored at room temperature $\left(\sim 23^{\circ} \mathrm{C}\right)$ for $24 \mathrm{~h}$. Also, the results showed that immediate storage of PEF treated apple juice at $5^{\circ} \mathrm{C}$ would enhance the microbial safety of the treated apple juice

\section{Acknowledgement}

The authors wish to thank Ms. Donyel Jones and Lee Chau for their technical support and Dr. John G. Phillips for assistance in statistical analysis of the data.

\section{References}

1. Alex Y-L. T, Ravishankar S, Sizer C E (2001) Effect of Low-temperature, highpressure treatment on the survival of Escherichia coli O157:H7 and Salmonella in unpasteurized fruit juices. J Food Prot 64:1122-1127.

2. Baired-Parker A, Davenport E (1965) The effect of recovery medium on the isolation of Staphylococcus aureus after heat-treatment and after storage of frozen or dried cells. J Appl Bacteriol 28: 390-402.

3. Black E P, Kelly A L, Fitzgerald GF (2005) The combined effect of high pressure and nisin on inactivation of microorganisms in milk. Innovative Food Science and Emerging Technologies 6:286-292.

4. Cody SH, Glynn MK, Farrar JA, Cairns KL, Grifin PM, et al. (1999) An outbreak of Escherichia coli O157:H7 infection from unpasteurized commercial apple juice. Ann Intern Med 130:202-209.

5. Dutreux N, Notermans S, Wijtzes T, Gongora-Nieto MM, Barbosa-Canovasa GV (2000) Pulsed electric fields inactivation of attached and free-living Escherichia coli and Listeria innocua under several conditions. Inter J Food Microbiol 54: 91-98

6. Geveke DJ, Brunkhorst C (2003) Inactivation of Saccharomyces cerevisiae with Radio Frequency Electric Fields. J Food Prot 66:1712-1715.

7. Geveke DJ, Brunkhorst C (2004a) RFEF pilot plant for inactivation of Escherichia coli in apple juice. Fruit Processing 14:167-170.

8. Geveke DJ, Brunkhorst C (2004b) Inactivation of Escherichia coli in apple juice by radio frequency electric fields. J Food Sci 69:134-138.

9. Geveke DJ, Kozempel M, Scullen OJ, Brunkhorst C (2002) Radio frequency energy effects on Microorganisms in food. Innov Food Sci Emer Technol 3:133 138.

10. Hauben KJA, Bernaerts K, Michiels CW (1998) Protective effect of calcium on inactivation of Escherichia coli by hydrostatic pressure. J Appl Microbiol 85:678-684.

11. Hulsheger H, Potel J, Niemann EG (1983) Electric field effects on bacteria and yeast cells. Radiation and environmental biophysics 22:149-162

12. Jeyamkondan S, Jayas DS, Holley RA (1999) Pulse electric field processing of foods. A review. J Food Prot 62:1088-1096

13. Kovacs E, Lantos J, Marzarean H (1966) The effects of phage infection on the catalase induction of Staphylococcus aureus culture. Experintia 22:802-803.

14. Lin J (1963) Studies on Staphylococcus catalase. Report 1. Effect of antibiotics on catalase biosynthesis in intact Staphylococcus cells. J. Formosan Med Assoc 62:310-316

15. Linton M J, McClements, Patterson MF (1999) Inactivation of Escherichia col $\mathrm{O} 157: \mathrm{H} 7$ in orange juice using a combination of high pressure and mild heat J Food Prot 62:277-279.

16. Mackey BM, Seymour DA (1987) The effect of catalase on recovery of heatinjured DNA-repair mutants of Escherichia coli. J Gen Microbiol 133:1601-1610.

17. Martin SE, Flowers RS, Ordal J (1976) Catalase:Its effect on microbial enumeration. App Environ Microbiol 32:731-734.

18. Mason J (1994) Salmonella Enteritidis control programs in the United States. Int J Food Microbiol 21:155-169.

19. Mazzotta AS (2001) Thermal inactivation of stationary-phase and acid adapted Escherichia coli O157:H7, Salmonella, and Listeria monocytogenes in fruit juices. J Food Prot 64:315-320. 
20. Miller RG (1981) Simultaneous Statistical Inference, 2nd Edition. SpringerVerlag, New York 67-70.

21. Molina-Hoppner A, Doster W, Vogel RF, Ganzle M (2004) Protective effect of sucrose and sodium chloride for Lactococcus lactis during sublethal and lethal high-pressure treatments. Appl Environ Microbiol 70:2013-2020.

22. Min S, Min SK. Zhang QH (2003) Inactivation kinetics of tomato juice lipoxygenase by pulsed electric fields. Food Enger and physical Propert 68:1995-2001

23. Ponne CT, Balk M, Hancioglu O, Gorris GM (1996) Effect of radio frequency energy on biological membrane and microorganisms. Lebensm-Wiss U-Technol 29:41-48.

24. Sizer CE, Balasubramaniam VM (1999) New intervention processes for minimally processed juices. Food Technol 53:64-67.

25. Ukuku DO, Geveke DJ, Zhang HQ, Cooke PH (2008) Membrane damage and viability loss of $\mathrm{E}$. coli K-12 in apple juice treated with radio frequency electric fields treatment. J Food Prot 71:684-690.
26. Ukuku DO, Geveky JD (2010) A combined treatment of UV-Light and radio frequency electric field for the inactivation of Escherichia coli K-12 in apple juice. Inter J Food Microbiol 138:50-55

27. Virto P, Manas P, Alvarez I, Condon S, Raso J (2005) Membrane damage and microbial inactivation by chlorine in the absence and presence of a chlorinedemanding substrate. Appl Environ Microbiol 71:50222-5028.

28. Woo IS, Rhee IK, Park HD (2000) Differential damage in bacterial cells by microwave radiation on the basis of cell wall structure. Appl Environ Microbiol 66:2243 2247.

29. Zhao W, Yang R., Rongrong L, Wang M, Qian P, et al. (2008) Effect of PEF on microbial inactivation and physical-chemical properties of green tea extracts. Lebensm-Wiss. U-Technol 41:425-431

30. Zimmerman U, Pilwat G, Rieman F (1976) Dielectric break-down of cell membrane. Biophys J 44:881-889

31. Zimmerman U (1986) Electric break-down, electropearmeabilization and electrofussion. Rev Phyio Biochem Pharmacol 105:175-256. 